\title{
Role of Women in Tulama Oromo Gada System: The Case of Ilu, South-West Shewa Zone, Oromia Regional State
}

\author{
Aregash Eticha Sefera \\ Faculty of Social Sciences and Humanities, Bule Hora University, P.O.Box 144, Bule Hora, Ethiopia
}

\begin{abstract}
This study deals with the role of women in Gada system in Tulama Oromo of Ilu. Gada is an indigenous institution that incorporates political, social and economic issues of the Oromo. In this institution, Women have their own role and status in the political, social and economic affairs of the Oromo society. The objective of this study is to examine the role of women among Tulama Oromo of Ilu Gada system. To achieve this objective, both primary and secondary data was used. Accordingly, interview, focus group discussion and participant observation were employed to collect data. For this purpose, informants were selected from Abba Gada (father of Gada), Luba, Jaartii Cifree (wife of Yuba (retired Gada elder)), Haadha Siiqqee (wife of Abba Gada, Luba), community elders and culture and tourism office from government officials. These informants were participated in interview, focus group discussion. In such way, 36 informants were directly involved in the study. In anthropological studies, analysis is an instrument to extract meanings and interpretation from the data obtained during fieldwork. In such manner, data were presented in a qualitative type. The findings of the study show that women have tremendous role in gada system. In this case, no event or no ceremonies take place without the full participation of women. Women were basically represented and/or play a significant role through different institutions such as Siiqqee and other ritual ceremonies and institutions working as check and balances for protecting women's right in general. Hence, without participation of women, the Oromoo socio-political practices could be meaningless. That is to say, any social, political and economic practice irrespective of women may not be fruitful. Based on the research findings, some recommendations were forwarded that strengthen understanding of Gada system.
\end{abstract}

Key terms: Gadaa system; Oromo; Women; Tulama; Ilu.

DOI: $10.7176 /$ RHSS/9-19-02

Publication date:October $31^{\text {st }} 2019$

\section{Introduction}

In a society, gender ideology is created and reflected in multiple ways. Among the myriad ways, culture play great role in creating and reflecting gendered culture in a society (Jeylan, 2004: 103). Jeylan stated that one feature of gender ideology is that men and women are relational, socially constructed, culturally specific and negotiated categories.

The role of women in society is very diverse worldwide (Klingorovo and Havlicek, 2015). Some African society has customary law to protect women's human rights (Abass, 2010). For instance, among Kom of Cameroun, Kikuyu of Kenya, and Igbo of Nigeria, there is traditional decentralized democratic system with a grassroots-based leadership, and women had their own self-government in the political system. In these societies, women have economic power, strong social organization, and a deep sense of female solidarity (Amadiume, 1997).

Baines, (2012) argued that implementing customary law and institutions in constitutional rights encourage the protection of women's rights by bottom-up rather than top-down approach. The bottom-up approach is more likely to have the support of the community, with no cost to women. Otherwise, the community's opposition makes it harder, if not impossible, to implement women's rights by any mechanism. Therefore, implementing women's institutions customary law in light of present day condition have vital role in protecting violation of women's right (Abass, 2010).

Among the horn of African groups, the Oromo people are known for their egalitarian and democratic social system known as Gada and their military organization that enabled them to emerge as one of the strongest ethnic group in the Horn of Africa between the $12^{\text {th }}$ and mid-19 $9^{\text {th }}$ centuries (Assefa, 2011). Gada system could probably be taken as one of the prime examples of understanding of the notion of rights and duties in Africa. In addition to these shared features of traditional African leadership systems, its democratic nature and the sophistication of Gada system in maintaining balance among different political power positions as well as it's built mechanisms of checking these powers by independent institutions make it comparable to modern democracies and could provide a solid ground to build on (Geshe, 2013).

According to Melba (1988), Gada is an institution that governed the life of every individual in the Oromo society from birth to death. Under Gada governance, the Oromo created and sustained a powerful of Oromo people in the region for many centuries. Assefa (1993) stated Gada as a political, economic, social, and religious institution, was the pillar of the Oromo culture and civilization". Every male Oromo was born into one of the 
five age-grade sets. The Gada politico-military structures actively excluded women. But women wielded power and control in the domestic scene where they had de facto control over the most important resources (Asmarom, 1973; Bartels, 1983; Waqayyo, 1991).

On the other hand, however, women were considered as alagaa (outsiders or strangers) in the gosa (clan). They were not members of the gosa into which they were born, or the one into which they were married. They were rather bonds between the different families (Asmarom, 1973). However, there is a check and balance mechanism built into the Gada system by which Siiqqee was institutionalized, and women formed parallel organizations of their own which actively excluded men. Thus, the Siiqqee institution functioned hand in hand with the Gada system as one of its built-in mechanisms of checks and balances. Hence, these two institutions helped maintain safuu (ethical and moral code) in Oromo society by enabling Oromo women to have control over resources and private spaces, social status and respect, and sisterhood and solidarity by deterring men from infringing upon their individual and collective rights (Kuwee, 1991).

Women are also able to convince their husbands, sons, brothers and fathers to stop fighting and settle their cases through negotiation. Women have special skills and power in settling conflicts. As a result Oromo women formed collective struggle through building the siinqee solidarity (Kuwee, 1991).

In this study, efforts have been made to identify the role of women in Tulama Oromo Gada and women's participation in the associated social institutions and ceremonies among the Ilu Oromo of Ilu woreda of Oromia Regional State. Accordingly, this study examines the advent of Tulama Oromo Gada system of Ilu and examines the material artifacts used by women and men as well.

\section{Statement of the Problem}

There are misconceptions and misunderstandings among different writers and scholars about the status and the role of women in the socio-political life of the Oromoo that says the Oromoo Gadaa system excludes females from socio-political life. They also emphasized that women have no role and are not taking part in the three Gadaa government organs (Fille, 2017). Hence, the role of women in the Gada political power has created controversies among scholars.

Some argue that women were completely excluded from the Gada system while others strongly indicate that the women held a significant position particularly by referring to their institutions of Ateetee and Siiqqee. For instance, Dirribi (2011) describes that one of the shortcomings of the Oromoo Gadaa system is the exclusion of women from political participation. This means that they do not have the right to elect their representatives and to be elected as the member of the Gadaa higher government organs. Getu (2005) in his way also describes, it is commonly said that women are restricted to domestic work and are excluded from public activities, including conflict resolution.

However, Dirribi's and Getu's view from the above might have been emanated for one thing, from the replication of hasty generalization of foreign and local writers and researchers; second without conducting a thorough ethnographic research and without the triangulation of different foreign and local researches as well as publications. Thus, the view is different from yes. Because, even though women are excluded from executive organ, because of the domination of Oromoo culture by the previous regimes, still in different parts of the Oromoo major clans, they are playing a great role in solving political, economic and social conflicts that are created among the people (acting as judiciary organs).

Waqayyo (1991) indicated that the influence and positions of women in a Gada system is a matter of the structure of the society but not a matter of physiology. Kuwee (1991) on the other hand, employed historical study approach, focused on the Siiqqee institution among the Oromo in general. One area of controversy was the omission of women from holding political power being an Abba bokkuu or Abbaa Gada. The other point of exclusion was from attaining all Gada grades and age sets like males (Tesema, 2016).

In this regard, research have been undertaken to examine Gada system of different Oromo clans. Asmarom (1973) is one of the scholars who studied the structure of Borana Oromo's Gada system. His research is of invaluable contribution to understand Gada system of Borana Oromo. However; he undermined the role of women in the politico-military structures of Gadaa rule and women were not born into a Gada grade; they were only married into one. Kuwee (1997) also stated that the Gada system, which seemingly excludes women, has designed an institution known as Siinqee that actively excluded men. Hence, Kuwee only focused on Siiqqee institution to show the role of women in Gada system and her study was among the Oromo in general than on certain clan. Abera (1998) stated that there is evidence that in the old days, women played a very important role in opening negotiations to settle disputes that resulted from homicide among the Oromo.

Similarly Jeylan (2004) asserted that women have involved in rituals of conflict resolution. Both researchers were limited to role of women in conflict resolution than Gada system in general. Although, Qumbi (1989) elucidated that very old, the very young and all women, in the Gadaa system, are considered innocent and peaceloving. However, he did not point out the position and participation of women in the Gada institution.

In this paper therefore, a better understanding was created as if women have a great role and they have high 
status in the Gada system of Ilu of Tulama Oromo. It has also been identified and presented that Oromo women have their own independent institutions (Siiqqee and Ateetee) parallel to Gada that that help to protect their social, political and economic rights over the men. In light of this, the study was initiated and aimed to examine the role of women in Tulama Gada system of Ilu by addressing the following questions;

\title{
Research Questions
}

$\checkmark$ How Tulama Oromo Gada system of Ilu was started and its major emphasis?

$\checkmark \quad$ What are the role and position of women in Gada system of Tulama Oromo of the study area?

$\checkmark$ Are there material artifacts that help to symbolize both men and women in Gada system?

\section{Objectives of the Study \\ General Objective}

The general objective of this study was to examine the role of women in Gada system of Tulama Oromo of Ilu.

\author{
Specific Objectives \\ * To examine the advent and major emphasis of Tulama Oromo of Ilu Gada system. \\ * To identify role of women among Tulama Oromo Gada system in the study area. \\ * To explore material artifacts that help to symbolize both men and women in the study area.
}

\section{Scope of the study}

This study was delimited geographically, thematically and methodologically. Geographically the study was conducted in Ilu woreda where Gada system of Ilu Oromo takes place. Thematically, the study concentrates on gender in Tulama Oromo Gada system. This study included Gada Leaders (Abba Gada), Luba, Haadha Siiqqee and culture experts. Methodologically, this study used qualitative approach and methods used in the collection of data were key informant interview, Focus group discussion, and participant observation.

\section{Limitation of the study}

A time constraint was a major problem in my study. I only had two months fieldwork which is a too short for anthropological study. The other one was challenges in obtaining previously recorded secondary data. Particularly, data on overview of Ilu woreda, Gada leaders (Abbaa Caffee) and Haadha Siiqqee due to they were not interested to give information as well as they are not available. During interview, obtaining culture and tourism office's experts with sufficient knowledge and experience on Gada system was a not easy task.

\section{Theoretical Framework}

A number of studies indicate that a researcher is usually unable to investigate a problem from all perspectives concurrently; he/she is expected to articulate the problem within a certain theoretical framework. Theoretical framework, as it is known, is the ideal construction or "the structure, the scaffolding, or the frame of the study" that can support a given research by introducing and describing various sets of ideas and enables the researcher to make sense of the data collected (Given, 2008). It also establishes a perspective or a set of lenses through which the researcher views the problem. Hereunder, an attempt was made to discuss the theoretical framework of the study to establish a vantage point through which the researcher views the problem.

Accordingly, structural functionalism theory is selected to be used as lenses for viewing the problem and interpreting the data. The theory is selected for its relevance or appropriateness, ease of application, and explanatory powers while talking about roles of women in Gada system of Ilu Oromo of Tulama. According to the theory of structural functionalism, social institutions are functionally integrated to form a stable system, and a change in one institution will precipitate a change in other institutions. Societies are seen as coherent, bounded and fundamentally relational constructs that function like organisms, with their various parts (social institutions) working together to maintain the whole.

Hence, to maintain the whole system of one institutions, all have own role. In the same manner, Gada system is one of the social institution in which both women and men collectively play social, economic, religious and political roles of the system. It is the system known by its incorporated to maintain society's internal integrity and survives over time. Therefore, the system cannot operate and function without the participation of women.

Similarly, the theory of interpretive anthropology of Clifford Geertz is one of the theories that can help me in interpretation of the symbolic representations in Gada system. The importance of symbolic or interpretive anthropology is that it is an instrument for examining specific aspects of a society that involve symbolic representation to interpret the social structure and what is respected to a particular society. It is important to know meaning, beliefs, values, worldviews, forms of feeling, and styles of thought in terms of which particular 
peoples construct their existence and live out their particular lives (Geertz, 2002).

Therefore, there are many symbolic representations in Gada system. Hence, it is appropriate theory to interpret the data.

\section{Research Methodology and Data collection Methods}

To examine the role of women in Gada system of Tulama Oromo of Ilu woreda, I employed qualitative research approach. For the reason that, the nature of the topic itself force me to decide to use this approach. Qualitative approach has been used to collect the perception and attitudes of people in the study area regarding the role of women in Gada system, advent of Ilu Gada system of Tulama Oromo. In addition, this approach has been used to explore material artifacts both men and women used in Gada system. To do so, interview (semi-structured), participant observation and focus group discussion were employed to collect data from different sources. In addition to primary sources, a secondary source was used.

Purposive and Snow ball sampling were used to select the participants for the qualitative data where informants were selected based on their experiences. They were also selected based on knowledge and position in Gada system and community as well. Participants working in Culture and Tourism Office of Ilu woreda were purposively selected based on the responsibilities they have in their office. Accordingly, Abba Gada, Luba, Jaartii Cifree, Haadha Siiqqee (wife of Abba Gada), researchers and religious elder (Qaallicha) were involved participated in the study. In such way 36 informants were directly involved in the study. On the process of the interviews, there were situation in which some informants informed me to other informants who had better understand of the subject under study.

\section{Data Collection Methods}

To achieve the study objectives, I employed both primary and secondary sources. The primary data was gathered through interviews (semi-structured interview), focus group discussion and participant observations. Secondary data was collected through a critical review of related literature.

\section{Interview}

In this research, I conducted interview as primary data collecting tool. Interview allows person to person discussion. Such discussion provides the opportunity to have a deep understanding of one's beliefs, feelings and behaviors on important issues. Thus, employing interview hopefully provide more accurate data (Solomon, 2017). In this study, I used semi- structured interview methods. This method of data collection gave freedom for informants to express their attitude, behavior, beliefs and knowledge openly in wording and answering questions for me. Thus, issues concerning the subject under study were collected through developing interview guideline that contains a series of open ended questions. In such way, interview was conducted with Abba Gada, Luba, Jaartii Cifree, Haadha Siiqqee (wife of Abba Gada), researchers and religious elder (Qaallicha) in various times to understand their views and concerns about role of women in in Gada of Ilu of Tulama Oromo. In general, informants were selected by considering their diverse knowledge in terms of their experience, age, work, position and gender. Accordingly, 15 informants were interviewed. Finally, all important information was transcribed and described.

\section{Participant Observation}

In qualitative research, data collection is done in the natural setting where the researcher immerses himself /herself into the community and makes the necessary observation (Maykut \& Morehouse, 2005). Participant observation was another technique that was used in the study to gather data. Participant observation gives an intuitive understanding of what's going on in a culture and allows speaking with confidence about the meaning of data. Participant observation makes strong statements about cultural facts that have been collected. It extends both the internal and the external validity of what you learn from interviewing and watching people. Participant observation helps to understand the meaning of observations (Russell, 2006). Participant observation is a significant method of data collection in order to understand the situation deeply as well as to collect reliable information.

In my study, I used participant observation method. During Buttaa ceremony, I involved in the ritual with haadha siiqqee (wife of Abba Gada) and Jaartii Cifree (wife of yuba) and followed was going on in the ceremony. I have involved in the ceremony at the time Abba Caffe, Luba (currently on the power) were gathering together around the river bank and blessing, singing and praying for their God. Also I observed the actual practices of Gada ceremony like when they were going to each other's home as well as during their circumcision cultural materials (like Caасcuu, Siiqqee, Callee and clothes worn by two sexes) used during ceremony; practices performed by participants and how women are incorporated in the Gada ceremony. As well as I observed how women incorporated in guddifacha ceremony and in what way rakoo ritual takes place in Gada system. Finally, I received data through video and picture of participants. 


\section{Focus Group Discussion}

According to Bryman, there are several reasons for using focus groups as a data collection tool. Among other things conducting an FGD helps the researcher to develop an understanding about why people think the way they do (Bryman, 2012). Therefore, considering the advantage of conducting a focus group discussion, it conducted with various categories of informants with the aim of accessing a broad range of views about the topic under study. In this study, focus group discussion was used to produce information on topics that require group viewpoints and sometimes consensus or disagreements.

Depending on this, I arranged three focus groups discussion, of which one FGD is a group of women( Jaartii Cifree and Haadha Siiqqee) and one FGD from men, Yuba and Luba, one group from knowledgeable people outside of members of Gada. Each group includes seven individuals. I undertook the discussions by preparing checklist for focus group discussion and at suitable time and place selected depend on the agreement of the participants. Generally, the purpose of focus group discussion was to generate and cross check data gather from individual informants and to gain general information about the role of women in Gada system of Ilu Oromo. By this method, I received the necessary data by using audio recorder and digital camera. Additionally, I took field notes during the discussions.

\section{Secondary Sources}

Emphasis on written materials is providing guidelines for the most effective way of doing research. Hence, secondary data reviewed from available literature. Because, primary data must be supported by previous research and other pertinent documents in order to make this research richer in data and strengthen the argument for its accomplishment. The researcher used Internet Sources and other written materials like academic journals, articles, books, published and unpublished $\mathrm{PhD}$ dissertations and M.A thesis and government publications.

\section{Data Analysis}

Data analysis is one of the most important stages of any research. It is a step-by-step examination of issues and their connections. Data analysis is an inductive process where the data gathered from the informants are analyzed inductively building from particulars to general themes, and the researcher making interpretations of the meaning of the datall (Creswell. 2009). In anthropological studies, data analysis is an instrument to extract meanings from the information obtained during the field work. Hence, I used qualitative approach to analyze the data collected through interviews, focus group discussions and observations to answer the research questions and to achieve the stated objectives; I used descriptive and qualitative approach to interpret the data. The nature of qualitative analysis has helped to have interpretation of all the result of my argument. Therefore, the interviews have been transcribed precisely and then translated into English from Afaan Oromo. Through repeated reading and review of the collected data, analysis was made where themes and patterns have been identified. I have then summarized and explained the results by describing the major ideas.

\section{Research Site}

Ilu is one of the woredas (Districts) in Oromia Regional State. It is one of woredas of South west Shewa Zone. According to data obtained from interview with Ilu woreda culture and tourism office, Ilu is the name of the Oromo tribe which is derived from the Tulama branch. Ilu is sub clan of the three Tulama Oromo, Bacho, Daaccii and Jillee. It is one of Ja'an Bachoo (six Bacho) branches. Ilu divided into three lineages, including Bili, Faaracho and Hariiroo. While, Bili is hangafa (first born son) of Ilu, Faaracho is the second and Hariiroo is quxisuu (the junior son).

Ilu woreda is bordered on the south by Bacho, on the west by Dawo, on the north by west Shewa zone and on the east by the Awash River, In the North with Dendi District, In the North and North east with woreda, In the East with Sebeta Hawas woreda and in the South East with Tole woreda. Teji is the capital town and it's found on $55 \mathrm{~km}$ towards south west of Addis Ababa on main road of Jimma. Astronomically, Ilu woreda is located between astronomical grid of $8^{0} 33^{\prime} 36^{\prime \prime}-8^{0} 56^{\prime} 24^{\prime \prime} \mathrm{N}, 38^{0} 06^{\prime} 18^{\prime \prime}-38^{0} 34^{\prime} 12^{\prime \prime} \mathrm{E}$ and its total area is 288.3 $\mathrm{Km}^{2}$

\section{Results and Discussions}

After relevant information was collected, data presentation and analysis are the necessary step. Hence, this chapter includes results and discussions of data that were collected through both primary and secondary sources. Interview, focus group discussions (FGD), and participant observation were techniques employed to collect primary data on role of women in Tulama Oromo Gada system with specific reference to Ilu woreda. Secondary data were also utilized in the presentation and analysis part of this paper.

\section{Advent of Tulama Oromo Gada System}

Gada is a broad concept and a system that consist of various institutions. Gada is a holistic system of governance 
encompassing political, social, cultural, economic, and religious affairs of Oromo people. In Gada system, Oromo people grouped themselves into five parties, Duuloo, Birmajii, Michille, Roobalee and Horataa. According to data obtained from Caffe Taa'icha during interview, the nomenclature of these parties was based on after a phenomenon or whatever occurred during the governance of one particular party. He stated his ideas as follows;

For example, Roobalee named after rain. The fact that it rained heavily is indicated by the phase Roobalee. Duuloo was named after preparation for war. The fact that Oromos prepared a big war is indicated by the phase Duuloo and preparation of war. Birmajii was named after happy festival and dance. And Michille was named after war victory. Oromo had a great victory over their enemy and showed this by the phase Michille and best war. Horata is remembered and was named after years of excellent cattle breeding. These good years were phased as Horata and feeling.

(Source: Interview, May, 17, 2019)

According to Tulama Oromo Gada system of Ilu, there are five Gada parties. These five Gada parties are, Robale, Birmaji, Duuloo, Horataa and Michille. Each Gada parties pass through similar Gada grades. Every Gada grade lasts for eight years.

According to information obtained from interview, Tulama Oromo is a large clan in Oromo genealogy and settling in the region known as Shewa. Tulama Oromo are found in East Shewa, south west Shewa, and west Shewa zones of Oromia regional state. Tulama has three sub-clans. The major clans of Tulama Oromo are; Daaccii, Bachoo and Jillee. These three Tulama are commonly known as sadeen Tuulamaa (Tulama threes). Each clan has further divided into sub clan, smaller unit mana and balbala, which literally means house and door. Daaccii subdivided into three clans, Galan, obboo, and Soddo. Bacho is a large clan that has six sub clans known as Ilu, Uru, Meta, Garasuu, Wajituu, and Keku. Whereas another Tulama clan is Jillee, which is subdivided into sub clans. These are Gona, Warree, Gindo, Loyyaa and Siibaa.

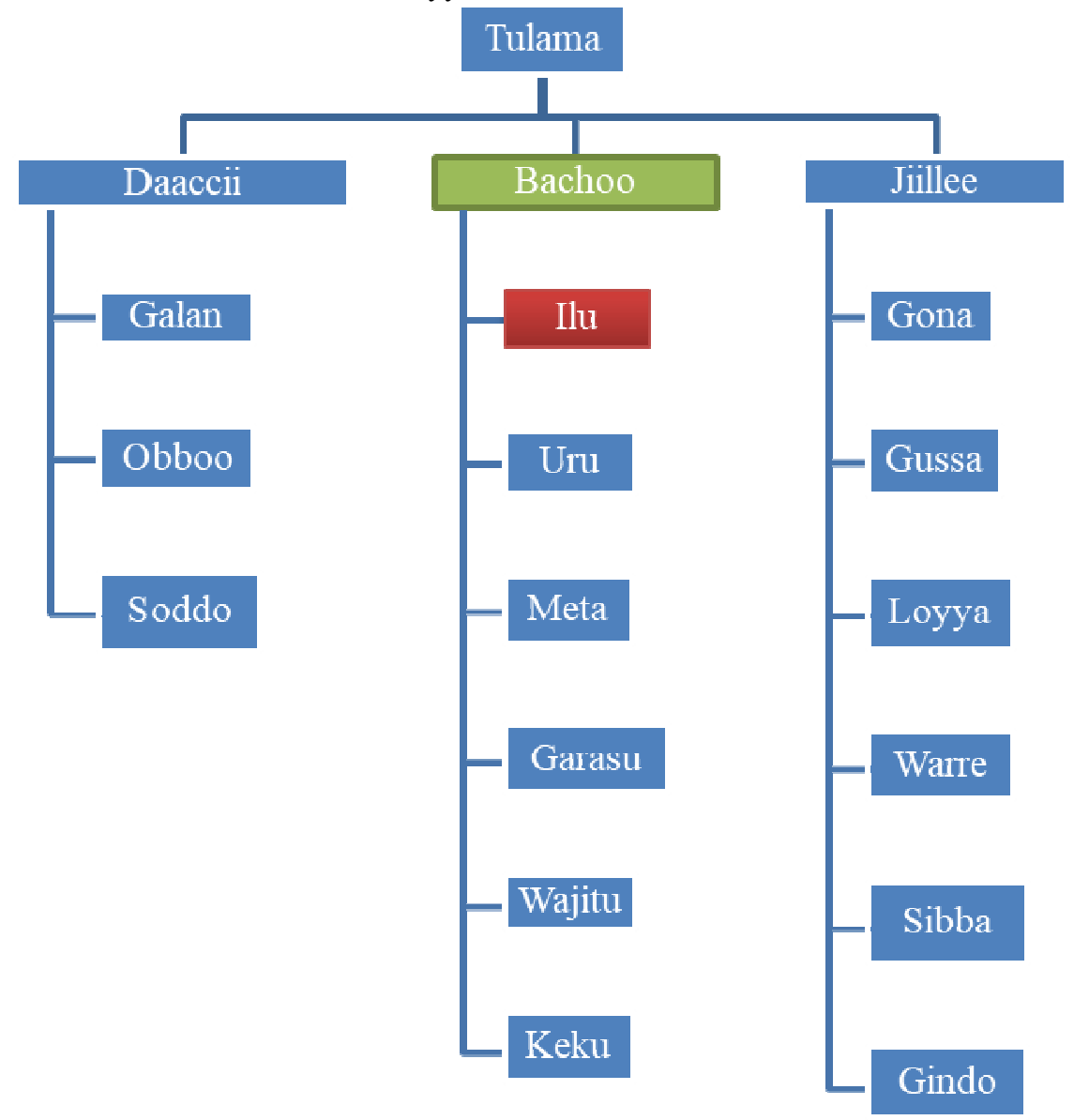

Figure 2: Genealogy of Sadeen Tuulamaa three Tulama

\section{Major Focus of Tulama Oromo Gada System}

According to data obtained through interview, the five Gada cycles transferring power from each other by the circulation of eight years. Gada laws improved every eight years at general assembly, Caffee. Caffee has the right to present cases to the multitude and ask permission to make new laws based on change and continuities in 
the socio political, religious and economic life of society.

Accordingly, the laws and the process of making new laws as well as reforming the existing laws in Tulama Gada system is part of Gada laws in Oromo society. Therefore, during this time the one who takes baallii (power) modify the existing law. Depending on this, Tulama Gada system emphasize on certain major areas. These are; law of life of human and damaged animals like cattle, hen, sheep etc., law of marriage and the law of Qaalluu.

\section{Law of Life}

According to the information obtained from key informant, the law of life of human gets a decision at the time of Caffee (assembly), when power transferring ceremony took place and Abba Gada/ Luba, Haadha siiqqee, Cifree and others gather together at Odaa Nabe (center of Tulama). On Odaa Nabe, the law of life proclaim to all living things. As per the law, if someone kill somebody, it has own compensation.

According to the principles of three Tulama gada systems, there is compensation (Guma) for the damage of human life. Guma is broad term stands for a ways of peace making between murderer and killed groups in order to maintain security of society and pay blood price. The payment for blood compensation is 150 birr, which known as dhangalaasa. Also Abba Gada (Caffee) decided 40,000 birr as a penalty on Horata/Melba Gada parties.

Even if killing is strictly forbidden in Oromo Gada system in general and Ilu in particular, if it is happened peace should be made between the two parties. The process of peace making through Guma in social and political conflicts among people is considering gender issues which involve both male and female.

In this case, Caffee taa'ichaa orders the clan of the murderer person to bring sheep, hiddii (solanum) and ninety nine cents and collect five spears, Kallacha and Caаcсuu and call the active members of the Gada party, Cifiree and the Luba and ask the families of the victim to receive the blood compensation. Virgin girls take gourd and grass, Haadha siiqqee hold her Caaccuu with Abba Gada pray to them for reconciliation. If the wounded party refuses the question for reconciliation, Cifiree (wife of yuba) will send to them. It is impossible to say "no" toward the question of Cifree.

Then, the next step is implementing law made by Caffee about the payment for injured body parts. The compensation for physically injured body parts include, hands (hands left and right hand), eye, and teeth are varies from place to place. Oromo believe that left hand is hugging the wife (husband hug his wife by his left hand, the wife give birth and bring about child. Therefore this implies fruitfulness. But in case of right hand, it works only for prepare food. However current Gada laws of Tulama promoted the compensation for each injured body seventy five birr, as a compensation and twenty thousand birr as punishment for the injured/wounded person/family.

Then, the two opposite groups stand up in front of each other, and reconciled by scattering solanum, cents and piercing the belly of the sheep alive and exchange greeting each other through the abdomen of the sheep. This process is known as harka dhiqaa (hand washing) in Gada system. The procedure of hand washing cannot be take place without women involvement. Then after, they bring about the peace between the two groups, and even they eat from the same dish.

\section{Mirga Namoomaa (Human rights)}

According to interview conducted with Caffee taa'ichaa, Gada system is a system in which human rights are properly respected. According to the Gada system, birmadummaa (freedom) is a natural right in which every person has the inviolable and inalienable right to life and liberty. This nature of the Gada system has enabled the Oromo people to treat each other equally. An Oromo who intends to leave his/her clan to settle among other clans, he/she has to request for permission and the host clan adopts the newcomer as one of the members of the clan. My informant added that, when a person seeks an asylum among the Oromo people, a ceremony is organized to adopt the person as one of them and hence forth, such person would have equal rights and obligations among the Oromo community he/she lives with. Therefore, in the Gada system, the fact that human rights are strictly respected has contributed to the prevalence of an outlook of freedom and liberty among the people, to believe in the equality of mankind, and to live harmoniously and peacefully with other ethnic groups.

\section{Seera Fuudhaa fi Heerumaa (Marriage law)}

Seera Fuudhaa fi Heerumaa (Marriage law) is one main focus of Ilu Gada system of Tulama Oromo. Thus, law of marriage emphasize on bride price, minimizing number of best man and best woman. As data gathered through interview with Caffe taa'ichaa, Caffee passed law of bride payment to pay six thousand birr for bride family. Gaafa deebii (when they return back by next to bride's house), bridegroom must pay two thousand birr with one sheep. Another decision is known as marga obboleessa (price of the brother) two hundred birr only. Current Gada system of Tulama passed the law of one to one marriage rule (monogamy). But if they broke this rule, either wife or husband, law of Tulama Gada punishes them. This situation follows many factors on family. This brings about economic crisis, when additional child added to the existing children, health problem and 
psychological problem, because he/she isolated from social interaction.

\section{Women and Gada Cycle of Tulama Oromo of Ilu}

As data gathered during interview with Haadha Siiqqee, female pass through Gada cycle depend upon their husbands. If men pass each Gada grades and cycle, up to power transfer ceremony, they are respected and have power with their husbands equally. However this is not mean that have no place in Gada system. They equally considered with men under Gada system. Gada system has five permanent parties whose members assume leadership once every eight years. Within forty years, all five parties serve their nation constituting

\section{Roobalee Birmajii}

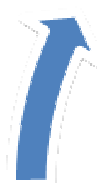

\section{Duuloo (Halchisa)}

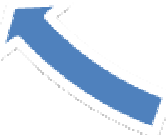

\section{Michillee}

\section{Horata}

Figure 3: Tulama Oromo Gada Parties and their cycle (Source: interview with Abba Caffe).

\section{Inclusion of women in Tulama Oromo Gada system}

The pre-existing literatures showed that women are totally excluded from Gada government system. However, historical and ethnographic evidences and varieties of valuable material culture uncovered the high status and significant role of women in the Gada government, more importantly in the legislative and judiciary organs (Fille, 2015). There are misconceptions and misunderstandings among different writers and scholars about the status and the role of women in the socio-political life of the Oromo that says the Oromo Gada system excludes females from socio-political life. They also emphasized that women have no role and are not taking part in the three Gada government organs. For instance, Dirribi (2011) describes that one of the shortcomings of the Oromo Gada system is the exclusion of women participation. This means that they do not have the right to elect their representatives and to be elected as the member of the Gada higher government organs. Getu (2005) in his way also describes, it is commonly said that women are restricted to domestic work and are excluded from public activities, including conflict resolution. Hence, there is controversy on whether women have role or not in Gada system.

According to data obtained from Caffe Taa'ichaa (Leader of assembly in Gada) during interview, women have their own role and status in the political, social and economic affairs of the Oromo Gada institution. For example, during the power transmission in the Gada system, women hold Siiqqee and the person who takes over the Gada power. In this event the newly elected officials walk under the Siiqqee sticks raised up by women standing in two rows and touching the other tips of their Siiqqee together. This implies that bring us peace, love and prosperity. The due respect of women's rights in Gada system has enabled women to play considerable role among their communities. According to data obtained data from interview, without participation of women, the Oromo socio-political practices could be meaningless. That is to say, any social, political and economic practice irrespective of women may not be fruitful. Thus, Oromo women have great role in exercising their political right in different ways in Gada system. All laws should be approved by women before speak out to the public by Abba Gada. Throughout different institutions such as guddifacha (Adoption), Guma (blood price), Rakoo (marriage laws), Ateetee and Siiqqee, women involve in these institutions and exercising their political right in different Gada rites and rituals. 


\section{Siiqqee Institution}

Siiqqee is symbol women's rights and hold when they go to attend social events. To show respect for Siiqqee, any individual cannot cross women hold Siiqqee until Haadha Siiqqee says oofkali (let success). Hence, anybody has obligation to respond to what Haadha Siiqqee asked. Based on the information obtained from Cifree during focus group discussion, in Tulama Oromo of Ilu, one of participants stated Siiqqee as follows;

Siiqqee is a stick that has a special respect. No one can use the stick to keep cattle, riding cart or beating animals like regular stick since it is a symbol of honor for married women. Mostly Siiqqee ritual stick is prepared from a tree known as harooressa because it does not tear easily. It is what differ married women from other. It holds during special event like during irreecha (thanksgiving), conflict resolution, ateetee ritual, adoption ceremony and social and natural problems. No one could cross women holding Siiqqee in any place, during irreechaa, ateetee etc. All people including Abbaa Gadaa and others Gada officials should give them respect.

(Source: Focus Group Discussion, April 09, 2019)

The above response shows that Siiqqee is a material artifact. But Siiqqee institution is an institution by which Oromo women fight for their rights and function side by side with Gada system by holding Siiqqee. This is an exclusively women's solidarity institution that is legitimatized by tradition and respected by society. It is a union that provides women with channels to participate in village councils and a cultural vehicle to mobilize women against violence and abuse. It is an institution in which women organize themselves in a group to stand up for their rights and control every movement in a society.

According to data obtained from interview with Culture and tourism expert of Ilu woreda, Siiqqee has both religious and social power that signifies women participation in the peace making processes along with elders. The power of Haadha Siiqqee is parallel to the power of Abbaa Bokkuu. When there is conflict between individuals, family members or inter family up to inter-clan conflict, Haadha Siiqqee intervene between the fighting and points siiqqee to the sky so as stop the fighting at the point.

Women's participation in the Gada Tulama is not only limited to peace making process. Further, women have a protective law in the Gada laws is also popularly applicable among Tulama Oromo Gada system. It is known as Seera Haadha (the law of mother). In the Gada system women have special places and the laws enforce that they should be respected, protected and served. Hence, the place of women in the Tulama Oromo is highly considerable and practically and inevitably, applicable among all members of the society. Thus, Siiqqee institutions functions hand in hand with Gada system and it has given big opportunity for Oromo women to articulate their views and addresses issues of concerning to women. Generally, I can say, Gadaa system and Siiqqee institution is a coin of opposite sides.

\section{Ateetee Ritual}

The Tulama Oromo women of Ilu perform ateetee ceremonies in respect of Maaram. It is believed that Maaram will help barren women to give a child, and help pregnant women to give birth to a child. On the other hand, ateetee is a sprit that comes upon women and worshiped as a traditional religion. According to one of my informant during interview with Jaartii Cifree, she stated ateetee as follows;

Women worship ateetee sprit by making different rituals. They come together from neighbor to worship Waaqa through this ritual. The women host ateetee sprit is prepared a big feast for the ateetee ritual and make sacrifice for the sprit. Women, who came for the ritual pray, sing and dance. The well-known singing during the ritual is '....ateetiyyoo....ililii, ililii...' ateeteen ililii jaalatti (ateetee loves 'ililii'). Then after, the neighboring women prayed to the sprit for their children, cattle. When they sing for cattle, 'ateetee kuullee too as taa'i fuullee too', (Atete my beauty be in front of me), 'Ateeten aannani yaa aannan yaa looni' (Atete is milk, a milk produced from cattle). Lastly, they eat and drink and go back to their home. On ateetee ritual, marqaa (porridge) and aannan (milk) are common.

(Source: Interview, May, 23, 2019)

This response shows that ateetee's has ritual functions as a prime source and protector of women individual's morality and it is a part of the belief system that women are closer to nature. Hence, it is a public gathering of women and it has both religious and social functions among the Ilu of Tulama Oromo.

\section{Role of Women in Blessing and Praying}

In Tulama Gada system of Ilu clan, male Abba Gada, Luba and female Haadha Siiqqee, as well as Jaartii Cifree are blessing and praying for their God at the center of Bacho clan, known as Caffee Ballo, a place where Odaa is founded. Women are blessing with men. Abba Gada cannot pray and bless for his God without the involvement of women. They bless as follows;

Hayyee yaa waaqa,

Sagaltama garbaa,

Saglan Borana
Oh our God

God of ninety oceans

God nine Borana 
Ciicoo gurraacha

Waaqa ja'an Galaan,

Waaqni saddeettan meexxoo,

Ni kadhanna,

Malka roobuu dide nuf roobaa

Kan hiyyoome ni durooma,

Dhugaadhan deemnet,

Malkaatti izgoo jennet

Kan nagayan nu bulchite

Dhugaa gaara godhi

Dhara sulula godhi

Ilmoo kan abba dhalchee godhi

Karra kan Abbaa horee godhi

Sanyii kan Abbaa qotatee godhi,

Niitii kan Abbaa fuudhee godhi

Oromo aadaadhan bulchi

Mootummaa algaarra bulchi

Oromoo waliin bulchi,

Seera kale nu jalaa hin jigsin,

Waaqni odaa shanani,

Waaqni gadaa shanani,

Waaqni waraana shanani,

Waaqni lubaa fi Cifree

Waaqa mucayyoo Guduruu uumte,

Waaqa mucaa Gaammee uumte,

\section{Black Ciicoo \\ God of six Galan \\ The God eighty Mexo}

We pray,

The rain which refuses us is rain for us,

Poor person become wealthy,

We relied on the truth

Let us pray to the river bank,

God who create male child with Gaammee started their praying with nature, then their society. At the end, they say waaqni lubaa fi Cifree (the God of Luba (male) and God of Cifree (female)). Again, waaqa mucayyoo Guduruu uumte (god who create long hair girl) and waaqa mucaa Gaammee uumte (God who create a Gaammee (male). Therefore, role of women also considered in praying God.

\section{Role of Women in Guddifacha (Adoption)}

Guddifacha is the customary adoption institution practiced by the Oromo society since ancient time. As local elders told me that although there is no adequate information when and how it emerged among the Oromo society, adoption has been one of the known institutions in Oromo culture in general and Tulama Oromo of Ilu clan in particular. One of my informant among yuba, stated guddifacha as follows;

Guddifacha is way of adopting child for a family who has no children. Guddifacha is the process of taking another family's child and making him/her a member of the family with all privileges, and responsibilities. It was one means of resolving childlessness and social integrity between families and clans. In this case, the adopted sons or daughters would have equal rights and privileges with the biological sons or daughters. The main reason for guddifacha is to enable childless couples to have children and heirs. The adopters would be father and mother, hold damma (honey) and make as adopted child drink during the guddifacha ritual. As a result, the guddifacha child is referred to as, ilmoo dammaa to mean that the child is born legally to the family.

(Source: Interview, April, 01, 2019).

In addition to this, as information gained through fieldwork observation, guddifacha is conducted both by female and male Oromo. During this ceremony, the family who want to adopt child from other people called Caffe taa'ichaa (Gada leader) and Gada elders. Caffe taa'ichaa provided five male from five Gada sets, and Jaartii Cifiree (wife of Yuba)'. These five male are; three people from Horata gada cycle, two people from Michille. In case, Horata is the senior (hangafa) in Tulama gada system and who are on the process of Buttaa ceremony in this year. In the procedure of Guddifacha, Jaartii Cifiree and Haadha Siiqqee hold their Siiqqee and Cаaccuu and the five male hold Eeboo Shan (five spears) and they sat on three legged stool. They bless for child adoption (guddifacha) as follows;

Barcumni Shan seeruma,

Eboon shan seeruma

Cifireen seeruma

Lubni shan seeruma

Dhugaa dubbadhaa

Waaqni guutuu haa taasisu
Five stools is law

Five spears is law

Cifree is law

Five Luba are law

Speak the reality

Let God perform everything 
Ilmoon damma nuuf haa taatu Waaqni qe'ee kana hin balleessin Nama soraa kana qabu haa ta'u Ilma maqaa nama kaasu haa ta'u The above blessing shows that this guddifacha cannot be held without the participation of women in the ceremony.

After they bless, Caffe taa'ichaa called them and replied as;

Yaa Warra uumaa

Ilmi dhalate kun dammaan dhalatee?

Seera dammaan itti naa guutaa

Then, the adopting family replied;

Eeyyee seera siif guunna.

Seerri isaa hin jiguu

Hin sosso'uu

Dammaan erga dhalatee,

Mucaa kana seera isaa dammaan itti guunnef

Oh family of nature

Let child be a honey for us

God keep this compound

Let he/she be the owner of the home

Let this child hold his family's nam

Here, the law of honey implies that honey considered as pure as well as sweet. Hence, the participants of the guddifacha bless this adopted child as his/her greeting, communication and personality be sweet like honey. That is why Oromo of Ilu select honey than other.

Again Jaartii Cifiree provides a law for them as follows;

Mucaan kun seera guutuu

Cifree Caffee bal'ooti

Uuman isaa guutudhaa

Hulluuqaadhaa
This child fulfill the law

Cifree of Caffee Bal'oo (a place of law enforcement)

His/her nature is full

Shall he/she pass all the law?

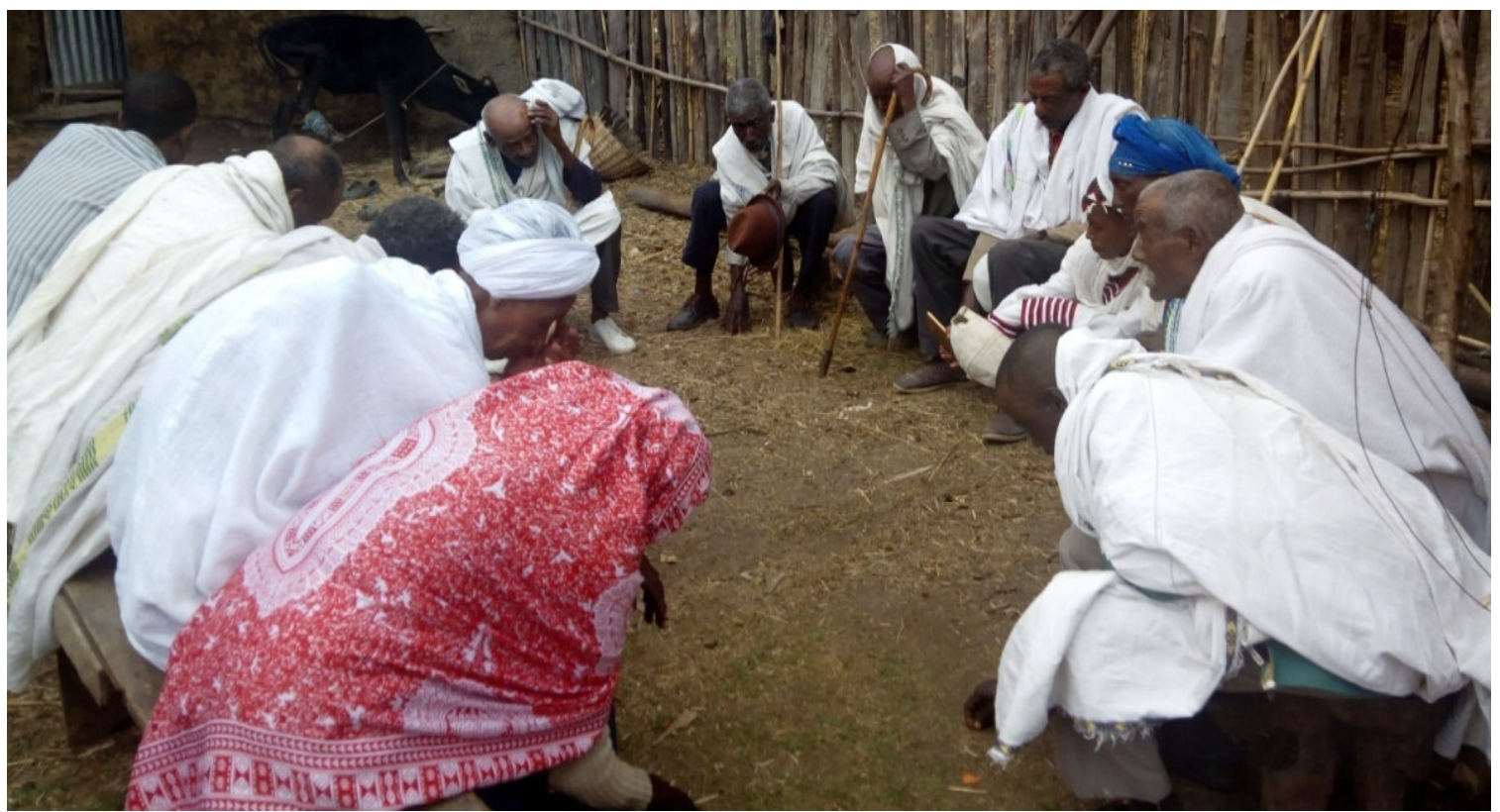

Figure 4: Blessing during Guddifacha ceremony (photo taken during field observation, April 2019.

Therefore, the above showed that, as women have a crucial role in Gada institution in general and guddifacha in particular. For example Jaartii Cifiree and haadha siiqqee play great role in advising, counseling, blessing and they have high status and respect among the Oromo people.

This implies that Gada system considers the equality of women with men in guddifacha ceremony.

In Gada system, family asset is controlled by women. Men have the responsibility of cultivating and harvesting as well as keeping the cattle and it is the responsibility of women to manage what is harvested and to allocate the proportion to be used for household consumption, to be sold in the market to earn cash, to purchase other goods and services needed by the family. The other social role of women is making prayers to waaqa on behalf of the whole nation.

According to obtained data during interview with Yuba, women have special role in praying to their God. Depending on this idea, he outlined as follows;

At a place where people gather for prayers, it is the women among the community who go in the front 
only seconded by little children. In particular, when there is a problem facing the community such as drought, epidemic outbreak, etc., they go to river or lake in the nearby carrying green grasses to perform the ritual of prayers so that 'Waaqa' intervene and solve their problem. This role of women is due to the belief that women have the power to mediate between 'Waaqa' and the whole community.

(Source: Interview, April, 19, 2019)

According to data obtained during interview with Luba, the various Gada rituals can never be conducted without the full participation of women. They are not completely absent from social, judicial and political decision making processes and official ceremonies. Assemblies cannot be held without their knowledge and consent. Decisions passed by the assembly necessarily must protect the rights of women. Even war and peace deals cannot be decided upon without the participation of women. There are institutions recognized by the Gada which are solely run by women. These include Siinqee, Ateetee and others. Those who say the Gada does not include or involve women have not read or studied about the system. Therefore, the total prohibiting of women in the Oromo Gada system is basically far from truth.

\section{Seera Rakoo (Marriage Law)}

In Gada laws the law concerning the relationship between husband and wife, social, economic and rights of children is known as seera rakoo this law focused on the respect and protection of female and children. According to information gathered through interview with Haadha Siiqqee, rakoo is a law, somebody practice for the respects and rights of his wife and children in Tulama Gada system. A person with bad manner and fails to respect the laws of family would not be given responsibilities in the societal administration. Rakoo is a promise between husband and wife that occurred during marriage. For long marriage without rakoo was not acceptable in society. Even if a person who has not practices rakoo, cannot take part in Buttaa ceremony. Immediately communicate with Caffee taa'ichaa and do as newly married individuals. By the rules of rakoo, women get a respect in society and she has the right to inherit the property of her husband's family.

\section{The Transfer of Power and Buttaa Ceremony in Tulama Gada System}

According to gada rules and regulations, the terms office of the elected Gada leaders was limited to eight years ending with a formal power transfer ceremony. All clans of the Tulama should attend the Baallii (power) transfer ceremony which was conducted at Odaa Nabe. The handover ceremony began one year before the actual transfer the power.

The next Gada ritual towards the transfer of power was the Buttaa ceremony. Buttaa was a ceremony of graduation or beginning into a Luba class. According to data obtained through participant observation, Buttaa was a transitional ceremony that involved large extensive ritual activities. This ceremony was a period when the strength of incoming Gada members (Luba) tested. Luba went to the Malkaa (river bank) at the eve of Buttaa ceremony. During Buttaa ceremony, Women hold marga (grass) and buqqee (gourd) filling with tella (local drink) going around the river with their husband. They pray to their and bless for the prosperity the earth and people. After the did these things they returned to their own home by singing in the following ways;

Gabbisayyoo hoo

Hayeen roobaa

Birbirsi hooda booranaa

Awashi birbirsi latee hoo

Caffee bal'oo odaan daraaree hoo

Hayyen roobaa

Birbirsi hooda booranaa

Gabbisayyoo hoo

Bara gada seerri ilmoorra mararaa

Andode mataa quranii hoo

Hin sodaatin yaa niitii luba

Xiqquma kutani hoo

Hayye roobee gala qilleensarra galee

Oh Gabisayo

Rain is raining

Birbirsa (pod corpus plant) is the norm of Borana

Birbirsa (pod corpus plant) is planting in Awash

Oda flowered in Café Balo

The rain raining

Birbirsa (plant) is the norm of Borana

Oh Gabisayo

The law is above child at the year of Gada

Andode (plant species) a head of sparse hair oh

Luba's wife don't afraid

They cut him slightly

This above stated song is sung both by male and female when they go to river to praying for their God. Buttaa ceremony involves the festivity of circumcision of Luba, and impaling ear. The process of impaling ear is take place by senior sister of Luba. She is literally known as gurra urtuu. The role of gurra urtuu is impaling Luba's ear and put into earring to her brothers

The current gada cycle who transfers power is Horata. Duuloo and Roobalee Gada sets were eaten from Horata as foollee and dabballee respectively. During this ceremony, dabballee and foollee sing and accept what they eat and drink at the house of Luba. They sung as follow;

Ofkali wayyaa Luba koo oofkali

Gadaan keeti taraan keeti oofkalii

Let success luba

It is your round, your Gada 
After they sung Luba, Dabballee and foollee sung separately as follows;

Dabballee dabboohoo yaa dabboo

Oh dabble

Dabballeen aannani naaf kenni aannan koo

Dabballee dabboo hooyaa dabboo,

Dabale is milk, give me a milk

Dabballee daa'ima kichuu loon sii tiksuu

When Foollee sing;

Foolliyyoo roobaa birbirsi daraaree

Lubatu na waamee yaa foollee

Foolliyyoo foolleen korma

Foollen korma korma yaaYadecho

Oh Dabble

Dabale is immature, shall I keep your cattle

At this time the wife of Abbaa Gada (Luba) provide a plenty food known as dhangaa like cuukkoo, araqee (local drink), tella and bread with butter for both group. She must sing with them and if she refuses, they may insult her. After they eat and drink, they need another dhangaa from the first born sister, gurra urtuu. They sing as follow and wait for additional food (dhangaa) from her.
Yaa magaazi qottoon muka hin murtu
Oh hand saw, axe cannot cut a tree

Gooftannaf kenne yaa giiftii

Lord gave,

Maafan dhaba Dhangaa gurra urtuu, $\quad$ Why I loss, Food of 'gurra urtuu'

If she late, they sing as follows;

Eegee qabee qeerransa eegee qabee

Barbaaddet dhabdemoo,

Machoofteti raftemmo

I hold the tail of tiger

\section{Gurra urtuu maafan si eegee dhabee $\quad$ Why I am waiting your dhangaa (food)}

She also prepares them in the same manner and sings with them and feed them. The journey of foollee and dabballee to the house of each Luba was continues from day to night. The ceremony stays for five days, for one Luba until he return back to the river. On the fifth day, they finalize the ceremony of Buttaa. Gurra urtuu has a role and respect in this event. If he has no sister, best man of Luba practice as his sister. Gurra urtuu malee seerri hin guutuu (without gurra urtuu the law of Gada ceremony cannot fulfill). This shows that as women actively participate in Gada system and ceremony. Without the involvement of them, it is impossible to practice Gada system.

\section{Material Artifacts Representing the Equality of Female and Male in Tulama Oromo Gada system}

Gada system composed symbolic cultural system that the Oromo had developed over time and used for long period.

According to data obtained focus group discussion with Luba, they explained as follows;

In Gada system, there are a number of material artifacts which represent both male and female. Both male and female are unique from each other based on the color of their clothes. Women wear dalgee (cultural clothes), wear scarf on their head, wear Callee aadaa (cultural necklace), and holds Caaccuu and Siiqqee.

(Source: Interview, May, 26, 2019)

Accordingly, Abba Gada and Luba wear marata (white clothes) on their head, put circle ear rings on their ear and hold Abba Gada's faajjii (flag), bokkuu as well as Siiqqee, especially during Gada ceremony. However, Abba Gada is a respected person and he cannot hold waan jal'aa (something which is not straight).

\section{Alangaa}

As obtained through interview with Abba Gada, he stated Alangaa as follows; Abba Gada holds alangaa. Alangaa (whip) is made up of hippopotamus skin and it's used only for Abba Gada. Alangaa is a law, Abba Gada hold alangaa (whip) and bokkuu and sit under Odaa and pray for to his God for peace, prosperity and fertility for the earth and people. For example, if somebody do wrong and if he curse, alangaa breakdown. But if he bless, the God give them what they need.

(Source: Interview, May, 11, 2019)

Further, he categorized alangaa of Abbaa Gada into three categories within their implication.

The first one is Alangaa diriirtu tokko (one straight whip), dhugaa tokko which means one truth. The second one is Alangaa diriirtu lama (two straight whip) dhugaa tokko fi dhara tokko this types of whip shows there are truth and false the third one is 'Alangaa diriirtu afur (four straight whips). Dhugaa, dhara, jireenya lafarraa fi $d u$ 'a. This also implies that there are four things. These are; truth, false, life on the earth and the last one is death.

(Source: Interview, May, 02, 2019) 


\title{
Siiqqee
}

As data gathered from focus group discussion with female, one informant explained Siiqqee as follows; Siiqqee a thin skin and made from harooressa (type of tree). It's used by Abba Gada and haadha Siiqqee. Siiqqee has its own law. Oromo women used Siiqqee to bless, to curse, when their rights are violated and to resolve conflicts among people.

(Source: Interview, April, 10, 2019)

It cannot use for look after a cattle. Oromo people cannot cross women with Siiqqee. It implies that women have a respect and safuu (moral values) in Oromo society. According to law of Siiqqee, if someone broke Siiqqee he punished eight cattle in Oromo society. According to data obtained from focus group discussion, siiqqee has significance for several things. Among these;

1. It serves as a symbol of independent. When mother of bride give siiqqee for her girl, it has a message of be yourself, certificate of be married.

2. It uses to settle a conflict between/within clan, family and etc.

3. To collect aid for poor individuals or whose property damaged.

4. Pray God for a woman who has no child.

5. To keep the security/safety of women who is on journey/tour. If she holds this siiqqee no one touch her.

6. Women use Siiqqee to pray their God for their people, cattle and living and non-living things.

\begin{abstract}
Abba Gada's Stick (Bokkuu)
Like Kallacha, it is believed that bokkuu is down from sky. The first bokkuu made from thunder. It is a symbol of power. It is respected but not as Kallacha. It is what Abba Gada hold bokkuu with alangaa interchangeably. It shows the equality of men and women. The top of the bokkuu shows masculinity, law and people. The bottom shows femininity, law and fecundity. Currently, bokkuu prepare from strait ejersaa, waddeessaa and horooressaa because of its strong, not easily break and tear.

As data obtained from interview with Caffe Taa'icha, Bokkuu is a respected material. Bokkuu is a sign of political power. Abba bokkuu holds bokkuu during peace resolution. Bokkuu is one of the artificial legal materials mainly hold by Abbaa Gada. Other high standing Gada officials also hold it as a symbol of authority and signifying the importance of Gada institution and its government. However, in addition to members of the Gada council, now days, it is common to see other Oromo males holding bokkuu during important public celebrations, religious ceremonies and even at wedding. Bokkuu is seen as identity marker and devotion of Gada law. It is also seen as gender marker. In the Tulama society, Bokkuu represents the participation of female and male in the enactment of the Gada law. Further, as Fille (2015) stated, a closer look at the features (shapes) depicted at the two ends of Bokkuu clearly shows the participation of male and female in the Buttaa rituals. Bokkuu has a swollen round shape at its one end (left) symbolizing male scrotum. At its opposite end, it has a bifurcated shape-symbolizing female's genital organ.
\end{abstract}

\section{Kallacha and Caaccuu}

Kallacha is a material that is highly respected next to Waaqa and wears over head by Abbaa Gadaa/bokkuu. As local elder told me that, it believed that initially Kallacha made from comet down from the sky with thunder. Then, Qaalluu/ayyaantuu spilled milk of black cow (because of its color is similar with sky) to the down Kallacha and covered with new cloth known. Finally, the down comet considered as Kallacha and thunder as Bokkuu. However, currently people prepare Kallacha from silver and other metals. The belt of Kallacha prepare from skin of python, crocodile and bull.

My informant added that Kallacha only be touched by kid, women, Qaalluu one times a year. It is prohibited to move here and there except for clan conflict, blood compensation and when drought happened to pray God and for reconciliation. Generally, Kallacha is too respected ritual material and no one resist against Kallacha in any situation. As one of my informant, Caаccuu and Kallacha are the ritual materials which have both religious and political background. Kallacha is highly respected material and considered as a cursing object. It's a significant in the process of peace resolution.

Parallel to Kallacha, Caaccuu is used by female. It's a symbol of fertility. In Oromo society, Abbaa Gadaa and haadha Caасcuu are identified from other members of the society possessing the ritual objects and role that they have in the socio political and religious life of society. Caaccuu prepare from elellaa (bread) and skin of hifer. Women use Саaccuu for blessing and praying than cursing. Also during irreecha (thanksgiving), ateetee, women use it with their Siiqqee to attend reconciliation event and others. Caaccuu and Kallacha use hand in hand.

\section{Conclusion and Recommendations}

Conclusion

As it is pointed out, the main purpose of this academic text is to examine the role of women in Gada system of 
Ilu Oromo. To this end, structural functionalism and symbolic interpretive theories have employed to interpret the data. As it is indicated in the literature, the role of women in society is very diverse worldwide. Some African societies such as Kom of Cameron, Kikuyu of Kenya and Igbo have customary law to protect women's rights. In the case of Oromo, the role of women in Gada system has created controversies among scholars. Some argue that women were completely excluded from the Gada system while others strongly indicate that the women held a significant position particularly by referring institutions and rituals such as ateetee, siiqqee, guddifacha and Guma.

In the case of Ilu Oromo Gada system, my ethnographic data revealed that women have seminal role and participation in day to day activities and its implication for exercising their rights. In this situation, Ilu Oromo women have played a great role in exercising their rights in different ways in Gada system. Women involves in power transfer ceremony, law enforcement as well as including different institutions such as, guddifacha (Adoption), Gumaa (blood price), rakoo (marriage laws), ateetee and Siiqqee institution.

Hence, the way they exercising their economic, socio-cultural practices are through rituals responsibilities in Gada institutions. The right of women in Gada system has enabled women to play considerable role among their communities. These women's participation is manifested by different material culture used in exercising their political, social and economic rights. Therefore, without participation of women, the Oromo of Ilu social, economic and political practices could be meaningless.

\section{Recommendations}

Based on the findings of this study, the following are recommended

$\checkmark \quad$ Valuing and promoting an indigenous culture has many advantages. We can learn from the strengths of Gada system. Hence, all concerned body should play own role.

$\checkmark$ Because of its complexity, it needs further investigation. Hence, I recommend our universities, and tertiary institutions to conduct research in detail on Gada system.

$\checkmark \quad$ Institute of Oromoo Studies (IOS) /Institute of Gada studies/Institute of Indigenous study, established in different University which are mandated to organize Oromoo studies should conduct research for better understanding of the Oromoo people and its cultural heritage.

$\checkmark$ For a long period of time, many researchers conducted research only on certain group of Oromo. Hence, this condition should be changed.

$\checkmark \quad$ Gada centers should be conserved accordingly.

\section{References}

Abass, Ademola (2010). Protecting Human Security in Africa. United States: Oxford University Press.

Abera, Jembere (1998). Legal History of Ethiopia 1434-1974: Some Aspects of Substantive and Procedural Laws. A. A: Faculty of Law, AAU.

Amadiume, Ifi (1997). Re-inventing Africa: Matriarchy, Religion and Culture: USA: St Martin's Press, Inc.

Asmarom, L. (1973). Gada: Three Approaches to the Study of African Society. Free Press, New York.

Assefa, Jaleta (2011). The Oromo in Exile: Creating Knowledge and Promoting Social Justice. Case Western Reserve University

Baines, Beverley, Daphne Barak-Erez, Tsvi Kahana (eds) (2012). Feminist Constitutionalism: Global Perspectives: USA: Cambridge University Press.

Bartels, Lambert (1983). Oromo Religion: Myths and Rites of Western Oromo of Ethiopia: An Attempt to Understand Berlin: Dietrich Reimer Verlag.

Bryman, A. (2012). Social Research Methods. Oxford University Press.

Creswell, J. W. (2009). Research design: Qualitative, quantitative and mixed methods approach. Los Angeles: Sage.

Dirribi Damusee (2011). Oromoo Wisdom in Black Civilization: Finfinne: Finfinne Printing and Publishing Enterprise.

Fille Jaleta (2015). Documentation of Folk Law of the Mecca Oromoo and Description of Grammatical Sketch: Addis Ababa University (Unpublished PhD Thesis). Addis Ababa:

Fille, Jaleta (2017). Include the Exclude: The Status and the Role of Women in the Oromoo Gadaa Institution: Proceedings of the $2^{\text {nd }}$ International Conference on Oromoo Studies: Jimma University: Ethiopia.

Geertz, Clifford. (2002). An Inconstant Profession: The Anthropological Life in Interesting Times: Annual Review of Anthropology, Vol. 31, pp. 1-19.

Geshe, Bona (2013). Local Characteristics under Ethiopian and South Africa's Constitution: Gada as a Foundation of the State Constitution of Oromia (MA Thesis): Central European University: Hungary.

Getu, Assefa (2005). Description and Documentation of Ateetee Ritual among the Dirree Enchini Community of West Shewa Oromoo Women: AAU: Addis Ababa, (Unpublished MA Thesis).

Given, Lisa M. (ed.) (2008). The Sage Encyclopedia of Qualitative Research Methods. California: Sage 
Publications, Inc.

Jeylan, Husen (2004). A Cultural Representation of Women in the Oromo Society: African Study Monographs, 25(3): 103-147.

Klingorovo, Kamila and Havlicek, Tomas (2015). Religion and Gender Inequality: The Status of Women in the Societies of World Religions: Moravian Geographical Reports: Vol. 23: Charles University: Prague

Kuwee Kumsa (1997). The Siiqqee Institution of Oromo Women: Journal of Oromo Studies: Volume 4, Numbers $1 \& 2$.

Maykut, P. \& Morehouse, R. (2005). Beginning Qualitative Research: A Philosophic and Practical Guide, London: The Falmer Press.

Melba, Gadaa (1988). Oromia: An Introduction. Khartoum: Sudan.

Waaqayyo, Qabbane (1991). Women's Influence in Oromo Society during the Period of Gada Rule. in Waldhaanso: Journal of the Union of ammo in North America, Vol. XVI, No. 2 pp. 3-14.

Qashu, L. (2016). Toward an Understanding of Justice, Belief, and Women's Rights: Ateetee: Arsi Oromo Women's Sung Dispute Resolution Process in Ethiopia. PhD Diss., Memorial

Qumbi, Liban R. (1989). The Participation of Oromo Women in the Gada System, their Slavery under Abyssinian Colonialism and their Present Struggle of National Liberation, in Waldhaanso, Vol. XIX, No. 3 (August, 1989) 17-25

Russell H. Bernard, (2006). Research Methods in Anthropology: Qualitative and Quantitative Approaches.4 ${ }^{\text {th }}$ ed. Alta Mira Press. UK.

Solomon, Debebe (2017). The Political and Religious Significance of Odaa Tree and Odaa Nabe among Tulama Oromo (MA thesis) Addis Ababa University: Ethiopia.

Solomon, Emiru (2017). Harnessing Gadaa System as a Black Covenant in Modern Constitutional Administration: Appraisal of Prospects and Challenges: Sociology and Anthropology 5(1): 52-62, 2017.

Tesema Ta'a (2016).The Gadaa System and Some of Its Institutions among the Borana: A Historical Perspective: EJOSSAH Vol. XII, No.2.

Tesema Ta'a (2017). Proceedings of the 2nd International Conference on Oromoo Studies on "Gadaa: The Indigenous Knowledge System of Oromoo,” Institute of Oromoo Studies (IOS): Jimma University. 